\title{
Chemical apportionment of southern African aerosol mass and optical depth
}

\author{
B. I. Magi \\ Atmospheric and Oceanic Sciences, Princeton University, Princeton, New Jersey, USA \\ Received: 7 June 2009 - Published in Atmos. Chem. Phys. Discuss.: 18 June 2009 \\ Revised: 22 September 2009 - Accepted: 26 September 2009 - Published: 13 October 2009
}

\begin{abstract}
This study characterizes the aerosol over extratropical and tropical southern Africa during the biomass burning season by presenting an aerosol mass apportionment and aerosol optical properties. Carbonaceous aerosol species account for $54 \%$ and $83 \%$ of the extratropical and tropical aerosol mass, respectively, which is consistent with the fact that the major source of particulate matter in southern Africa is biomass burning. This mass apportionment implies that carbonaceous species in the form of organic carbon $(\mathrm{OC})$ and black carbon (BC) play a critical role in the aerosol optical properties. By combining the in situ measurements of aerosol mass concentrations with concurrent measurements of aerosol optical properties at a wavelength of $550 \mathrm{~nm}$, it is shown that $80-90 \%$ of the aerosol scattering is due to carbonaceous aerosol, and the derived mass scattering cross sections (MSC) for OC and BC are $3.9 \pm 0.6 \mathrm{~m}^{2} / \mathrm{g}$ and $1.6 \pm 0.2 \mathrm{~m}^{2} / \mathrm{g}$, respectively. Derived values of mass absorption cross sections (MAC) for OC and BC are $0.7 \pm 0.6 \mathrm{~m}^{2} / \mathrm{g}$ and $8.2 \pm 1.1 \mathrm{~m}^{2} / \mathrm{g}$, respectively. The values of MAC imply that $\sim 26 \%$ of the aerosol absorption in southern Africa is due to $\mathrm{OC}$, with the remainder due to $\mathrm{BC}$. The results in this study provide important constraints for aerosol properties in a region dominated by biomass burning and should be integrated into climate models to improve aerosol simulations.
\end{abstract}

\section{Introduction}

Biomass burning is a major source of particulate matter in the atmosphere over Africa during the dry season. In southern Africa alone, biomass burning consistently accounts for $25 \%$ of the total number of fires that occur every year on the

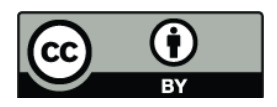

Correspondence to: B. I. Magi

(brian.magi@noaa.gov) planet (Giglio et al., 2003, 2006), but in situ measurements of tropospheric aerosol mass concentrations in that region are rare. This was part of the motivation for the Southern African Research Initiative field campaign in August and September 2000 (SAFARI-2000), and resulted in a number of publications from about 2002 to present, many of which are summarized by Swap et al. (2003).

This study synthesizes in situ measurements of aerosol mass concentrations obtained by aircraft in the southern African regional haze and originally published in SAFARI2000 studies by Eatough et al. (2003), Gao et al. (2003), and Kirchstetter et al. (2003). Measurements of aerosol mass concentrations made in smoke plumes are not discussed here, but there are detailed discussions by Eatough et al. (2003), Gao et al. (2003), and Kirchstetter et al. (2003). The synthesis of the regional haze measurements requires more than reviewing the research since there was a technical problem with part of the aerosol sampling system referred to by Gao et al. (2003) and by Kirchstetter et al. (2003). A solution to the problem is described in Sect. 2. Without this solution, aerosol mass concentrations presented by Eatough et al. (2003), Gao et al. (2003), and Kirchstetter et al. (2003) could only be analyzed independently. Hence, the synthesis provides a unified measurement-based estimate of aerosol mass concentrations over a region of the world that is poorly simulated in most transport and circulation models (e.g. Ginoux et al., 2006; Kinne et al., 2006; Matichuk et al., 2007; Magi et al., 2009).

The aerosol mass concentrations in this synthesis are combined with self-consistent aerosol optical properties discussed by Magi et al. (2008) to derive values of the mass scattering cross section (MSC) and the mass absorption cross sections (MAC) at a wavelength of $550 \mathrm{~nm}$ for measured aerosol species that are relevant to models. Finally, the total scattering and absorption of the southern African aerosol is apportioned into species contributions. Methods

Published by Copernicus Publications on behalf of the European Geosciences Union. 
are discussed in Sect. 2, results and analysis are presented in Sect. 3 and Sect. 4, and conclusions are summarized in Sect. 5.

\section{Methods}

\subsection{Background}

Gao et al. (2003) and Kirchstetter et al. (2003) discussed the methods of data collection and analysis, but they are briefly reiterated here. The teflon filter samples described by Gao et al. (2003) and the quartz filter samples described by Kirchstetter et al. (2003) (hereafter, referred to as G2003 and K2003, respectively) were collected in tandem on a manifold that pulled air through an inlet from outside the aircraft, across the filters, and exited the aircraft through an outlet. The inlet (Sinha et al., 2003) had a 2-3 $\mu \mathrm{m}$ particle diameter cut-off such that all reported results apply to $\mathrm{PM}_{2.5}$ (i.e. particulate matter, PM, with diameters less than $2.5 \mu \mathrm{m}$ ). Independent in situ evidence shows that the number concentration of the southern African aerosol in the polluted layer (below about $5 \mathrm{~km}$ ) is dominated by particles with diameters less than $1.0 \mu \mathrm{m}$ (Li et al., 2003; Posfai et al., 2003; Formenti et al., 2003).

Teflon filter samples were analyzed by Gas Chromatography-Mass Spectrometry (GC-MS) for $\mathrm{PM}_{2.5}$ aerosol mass concentration, and the mass concentrations of $\mathrm{PM}_{2.5}$ ionic species like sulfate $\left(\mathrm{SO}_{4}^{=}\right)$and nitrate $\left(\mathrm{NO}_{3}^{-}\right)$, among others. For simplicity in this study, ionic species are referred to as $\mathrm{SO}_{4}$ and $\mathrm{NO}_{3}$. Quartz filter samples were analyzed by Evolved Gas Analysis (EGA) for $\mathrm{PM}_{2.5}$ carbonaceous aerosol mass concentration, which was usually apportioned into organic carbon (OC) and black carbon (BC) components. G2003 and K2003 provide much more detailed descriptions about the GC-MS and EGA techniques, respectively.

The sampling system used to determine aerosol mass concentrations reported by Eatough et al. (2003) (hereafter, referred to as E2003) was completely independent of the manifold used to collect samples described by G2003 and K2003, but both sampling systems were on the same aircraft (see Appendix in Sinha et al., 2003). Using the Particle Concentrator Brigham Young University Organic Sampling System (PC-BOSS) to collect filter samples, E2003 used Temperature Programmed Volatization Analysis (TPVA), EGA, and Ion Chromatographic Analysis (ICA) to report mass concentrations of $\mathrm{OC}, \mathrm{BC}, \mathrm{SO}_{4}, \mathrm{NO}_{3}$, and semi-volatile organic carbon (SVOC). No other study has reported SVOC in southern Africa, and SVOC is generally thought to be lost during in situ sampling. OC and BC as reported by E2003 and K2003 does not include this additional mass.

Samples reported by E2003 were collected at a lower frequency than samples discussed by G2003 and K2003, but on average the samples all characterized the same aerosol.

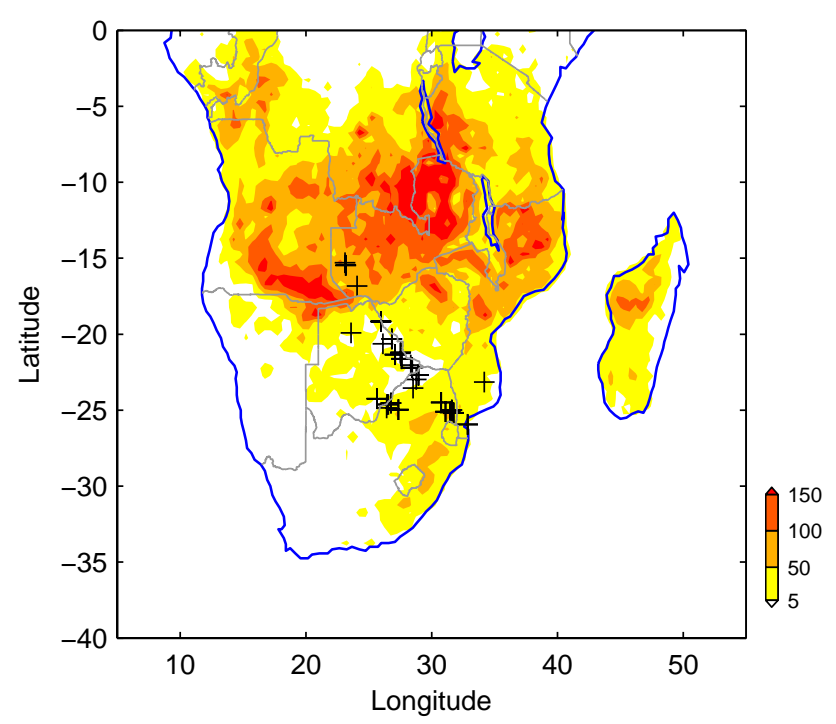

Fig. 1. Locations of filter samples collected during the SAFARI2000 field campaign (black crosses) and used in this study. Colors are mean (2001-2007) August and September fire counts derived from Moderate Resolution Imaging Spectroradiometer (MODIS) measurements (Collection 5) in units of fires per half degree gridcell.

Figure 1 shows the locations of samples discussed by E2003, G2003, and K2003. Formenti et al. (2003) discussed samples collected during SAFARI-2000, but further west of the major burning regions. Ground-based results reported by Piketh et al. (1999) and Maenhaut et al. (1996) were collected in southern to eastern South Africa, but our analysis is restricted to aerosol samples collected in the troposphere since groundbased filter data are not always representative of the aerosol characteristics aloft.

The results in this study are partitioned into categories based on the parcel back-trajectory analysis by Magi and Hobbs (2003). Namely, samples collected when backtrajectories were from the south or east are one category, while those collected when back-trajectories were from the north or west are a second category. The sample area roughly covers northeast South Africa, eastern Botswana, and southern Zambia (Fig. 1), and therefore parcels arriving from the south or east are extratropical (south of $22.5^{\circ} \mathrm{S}$ ) in origin, while those from the north or west are tropical (north of $22.5^{\circ} \mathrm{S}$ ) in origin. Therefore, samples are referred to as either characterizing the "extratropics" or "tropics" based on this discussion.

Since the tropics of southern Africa are more impacted by fires (Fig. 1), and the extratropics are relatively more impacted by industrial and dust sources (Piketh et al., 1999; Bond et al., 2007), differences in aerosol properties (such as chemical composition, size, or number concentration) between samples characteristic of the tropics and the extratropics are expected. The evidence showing the aerosol 
characteristics is summarized in Table 1, where the median aerosol optical properties at a wavelength of $550 \mathrm{~nm}$ and median aerosol physical properties are listed, along with the respective interquartile range. Aerosol optical depth (AOD) is one of the most commonly reported aerosol optical properties, and is calculated as the vertical integral of aerosol extinction (EXT) or retrieved from remote sensing measurements. EXT itself is the sum of aerosol scattering (SCA) and absorption (ABS), where EXT, SCA, and ABS are in units of $\mathrm{m}^{-1}$ or $\mathrm{Mm}^{-1}$. Single scattering albedo (SSA) is defined as SCA/EXT and physically represents the probability that radiation incident on a particle is scattered rather than absorbed.

The summary statistics in Table 1 are based on data discussed by Magi et al. (2008) and by Magi (2006). Over the tropics, AOD is significantly higher and SSA is significantly lower. AOD is higher due to the factor of two increase in accumulation mode particle concentration $\left(\mathrm{N}_{2}\right.$ in Table 1), and very little of the difference can be attributed to changes in the shape of the size distribution $(\alpha)$ or an increase in coarse mode particle volume concentration $(\mathrm{C} / \mathrm{F})$. Since relative humidity $(\mathrm{RH})$ affects ambient aerosol properties by increasing the size of the particles, which subsequently increases the AOD (e.g. Hegg et al., 1993), the median RH is listed in Table 1 as well. Magi and Hobbs (2003) showed that aerosol scattering coefficients in southern Africa are not significantly affected when RH is less than $\sim 50 \%$, so it is clear from Table 1 that RH cannot explain the AOD differences between the tropics and extratropics. The lower SSA in the tropics is due to a change in the overall chemical composition of the aerosol. The evidence supporting this assertion and the chemical species that contributed to the increase in AOD in the tropics is discussed in Sect. 3.

\subsection{Miscalibrated flow meters}

Mass concentrations derived from filters depends on the integrated flow volume $\left(\mathrm{m}^{3}\right)$ that passes across the filters. The three flow meters (Hastings Model TNALL) used to measure the flows for G2003 and K2003 were calibrated against a bubble flow meter before and after the SAFARI-2000 campaign and compared to a separate flow meter on the aircraft during the campaign. Each flow meter had a different set of calibration coefficients. In all cases, total flow was reported at standard temperature and pressure (STP, $273 \mathrm{~K}$, $1013 \mathrm{hPa}$ ) so that mass concentrations derived at different altitudes could be directly compared.

After the SAFARI-2000 campaign, we realized that the calibration coefficients of the flow meters were dependent on whether multiple flow meters were in use. The end result was that the total flows measured by the flow meters used for the filters reported by G2003 were in error by some unknown value. The flow meter used with the filters reported by K2003 were not affected because of the position of the flow meter on the aircraft manifold. This was verified qualitatively (simple observations during SAFARI-2000), but the
Table 1. Characteristic properties of the extratropical and tropical Southern Hemisphere African aerosol measured during SAFARI2000, which include the median values (and interquartile range, IQR) of aerosol optical depth (AOD), single scattering albedo (SSA), asymmetry parameter (ASY), relative humidity (RH), aerosol number concentration $\left(\mathrm{N}_{1}, \mathrm{~N}_{2}\right)$, coarse to fine particle volume ratio $(\mathrm{C} / \mathrm{F})$, and aerosol angstrom exponent $(\alpha)$.

\begin{tabular}{lrrrr}
\hline & \multicolumn{2}{c}{ extratropics } & \multicolumn{2}{c}{ tropics } \\
\hline & median & IQR & median & IQR \\
\hline AOD $^{\mathrm{a}}$ & 0.23 & $0.19-0.33$ & 1.07 & $0.72-1.11$ \\
$\mathrm{SSA}^{\mathrm{a}}$ & 0.89 & $0.87-0.91$ & 0.83 & $0.83-0.84$ \\
$\mathrm{ASY}^{\mathrm{a}}$ & 0.56 & $0.51-0.57$ & 0.58 & $0.5-0.59$ \\
$\mathrm{RH}(\%)$ & 31 & $29-32$ & 25 & $15-27$ \\
$\mathrm{~N}_{1}\left(\mathrm{~cm}^{-3}\right)^{\mathrm{b}}$ & 2904 & $1507-5441$ & 4930 & $4527-5075$ \\
$\mathrm{~N}_{2}\left(\mathrm{~cm}^{-3}\right)^{\mathrm{c}}$ & 632 & $442-768$ & 1326 & $986-1461$ \\
$\mathrm{C} / \mathrm{F}(\%)^{\mathrm{d}}$ & 2.66 & $1.80-2.91$ & 1.44 & $1.35-1.57$ \\
$\alpha^{\mathrm{e}}$ & 1.76 & $1.68-1.87$ & 1.85 & $1.77-1.87$ \\
\hline
\end{tabular}

a at a wavelength of $550 \mathrm{~nm}$;

$\mathrm{b}$ for particles with diameters $0.003-1 \mu \mathrm{m}$;

c for particles with diameters $0.1-3 \mu \mathrm{m}$;

$\mathrm{d}$ volume ratio of coarse mode particles (1-3 $\mu \mathrm{m}$ diameter) to fine mode particles (0.1-1 $\mu$ m diameter);

${ }^{\mathrm{e}}$ for extinction coefficient between 450 and $700 \mathrm{~nm}$.

flow meters were removed from the manifold before the calibration coefficients for the flow meters used for filters described by G2003 could be quantitatively verified. Therefore, although there were tandem filter samples, absolute comparisons between results by G2003 and by K2003 were not possible since one of the filter measurements (usually the teflon filters) used a flow meter with an unknown calibration constant.

As evidence of the problem introduced by the miscalibrated flow meter, the mass concentrations reported by G2003, K2003, and E2003 are summarized in Table 2. OC and BC reported by K2003 generally agreed with results by E2003 to within the bounds of the interquartile range or within the $\sim 30 \%$ measurement uncertainty. The agreement is better in the extratropics (Table 2a) than in the tropics (Table 2b), but this could be because the sample size of E2003 filters representative of the tropics is only four. However, results by G2003 (measured at the same time as K2003) do not agree with the results by $\mathrm{E} 2003$ (referring to $\mathrm{PM}_{2.5}, \mathrm{SO}_{4}$, and $\mathrm{NO}_{3}$ in Table 2). The discrepancy is most clear when the ratio of aerosol mass concentrations from the tropics to the extratropics is examined. G2003 results suggest a tropics to extratropics $\mathrm{PM}_{2.5}$ ratio of 0.8 , while E2003 results suggest a ratio of 3.1. The corresponding ratio of OC for K2003 3.5, while for E2003 is 5.8. Thus, G2003 data suggests that $\mathrm{PM}_{2.5}$ decreases in the tropics, while E2003 suggests an increase. Yet, OC reported by K2003 and E2003 clearly increases in the tropics due to more widespread burning as observed by 
Table 2. Comparison of median aerosol mass concentrations $\left(\mu \mathrm{g} / \mathrm{m}^{3}\right)$ and interquartile range (IQR) reported by Gao et al. (2003), G2003, and Kirchstetter et al. (2003), K2003, versus those reported by Eatough et al. (2003), E2003, for samples representative of Southern Hemisphere African (a) extratropics and (b) tropics. K2003 had a reasonable calibration, while G2003 did not, and these results have not been corrected to account for the miscalibrated flow meters (Sect. 2). E2003 results were based on measurements from an independent inlet.

\begin{tabular}{rrrrrr}
\hline & data source: & \multicolumn{2}{c}{ G2003 and K2003 } & \multicolumn{2}{c}{ E2003 } \\
\hline & species & median & IQR & median & IQR \\
\hline (a) & $\mathrm{PM}_{2.5}$ & 22.7 & $16.6-36.9$ & 14.0 & $8 .-27.4$ \\
& $\mathrm{OC}$ & 4.2 & $3.4-5.1$ & 3.5 & $3.4-9.3$ \\
& $\mathrm{BC}$ & 0.8 & $0.7-1.3$ & 0.9 & $0.5-1.8$ \\
& $\mathrm{SO}_{4}$ & 6.0 & $4.7-12.0$ & 4.0 & $1.8-6.5$ \\
$\mathrm{NO}_{3}$ & 0.4 & $0.3-0.5$ & 0.2 & $0.1-0.4$ \\
(b) & $\mathrm{PM}_{2.5}$ & 19.1 & $14.1-20.1$ & 43.7 & $31.1-63.6$ \\
& $\mathrm{OC}$ & 15.0 & $10.5-20.3$ & 23.2 & $17.1-36.2$ \\
& $\mathrm{BC}$ & 3.8 & $2.6-5.1$ & 1.8 & $1.4-1.8$ \\
& $\mathrm{SO}_{4}$ & 1.0 & $0.9-1.1$ & 7.7 & $5.7-8.1$ \\
& $\mathrm{NO}_{3}$ & 0.8 & $0.5-1.0$ & 2.8 & $2.0-5.6$ \\
\hline
\end{tabular}

satellite (Fig. 1). Table 1 provides further evidence of the discrepancy by showing a significant increase in AOD and accumulation mode aerosol number concentrations (Sect. 2.1) with no evidence supporting a significant change in the dominant particle size of the aerosol size distribution (i.e. $\mathrm{C} / \mathrm{F}$ and $\alpha$ in Table 1). The major reason for the difference in AOD in the samples is thus due to an increase in aerosol number concentration, and therefore an increase in $\mathrm{PM}_{2.5}$ mass is expected. G2003 results in Table 2 contradict this evidence, while E2003 and K2003 support the evidence.

\subsection{Proxy calibration}

In order to partition the aerosol mass or make any generalizations about measured aerosol mass, absolute mass concentrations must be used. A working solution to overcome the problem of miscalibrated flow meters was developed based on three separate pieces of information: 1 . we knew which flow meters were used to measure flow for each sample, 2. on four occasions, duplicate samples were collected by sampling aerosol on pairs of the same type of filters (twice with teflon, twice with quartz) and monitoring the flow rate through each filter using different flow meters, and 3 . the independent sampling system (and flow meter) described by E2003 was on the same aircraft.

The simultaneous filter samples, which should report nearly identical mass concentrations, were crucial to formulating a working solution. The intended purpose of the simultaneous filter samples was to characterize the noise inherent in the measurements of filter mass for the techniques described by G2003 and by K2003, but they resulted in a convenient solution to the miscalibrated flow meter. The results of the simultaneous filter samples are listed in Table 3 as Test 1 and Test 2 (obtained on two different days), and it is clear that there are discrepancies well beyond the expected noise (which should have been much less than 10\%) in reported mass concentration. Namely, the Test 1 results from "Flow Meter 1" for teflon filters $\left(\mathrm{PM}_{2.5}, \mathrm{NO}_{3}, \mathrm{SO}_{4}\right)$ and for quartz filters (OC, BC) should be roughly the same as the results from "Flow Meter 2". Similarly, Test 2 results from "Flow Meter 2" and "Flow Meter 3" should be roughly the same as well. Generally, Flow Meter 2 was used to derive measurements reported by K2003, while Flow Meter 1 and Flow Meter 3 were used to derived measurements from the teflon filters.

Purely by coincidence, the teflon filters obtained from the tropics were derived using Flow Meter 1 while the extratropical samples were obtained using Flow Meter 3. All quartz filters were obtained using Flow Meter 2, which was correctly calibrated (i.e. unaffected when multiple flow meters were in use). Using Table 3, the median ratio of mass concentrations reported by Flow Meter 2 to mass concentrations reported by Flow Meter 1 was 3.4 (interquartile range of 3.1 to 4.3), while the ratio of Flow Meter 2 to Flow Meter 3 was 0.5 (0.4 to 0.5 ). Assuming the mass (in $\mu \mathrm{g}$ ) reported in Table 3 should be equal, the fact that the ratios were greater than or less than unity is due entirely to difference in the flow (in $\mathrm{m}^{3}$ ) and we can use this as a proxy for direct calibration.

Evidence supporting this proxy calibration using Table 3 comes from the third piece of information. Because all the teflon filter samples (i.e. G2003) from the tropics were collected using Flow Meter 1, the ratio of mass concentrations reported by E2003 for the tropics to mass concentrations reported by G2003 for the tropics (listed in Table 2) should be similar to the ratio of Flow Meter 2 to Flow Meter 1 (stated above as 3.4). The ratio of mass concentrations in the tropics is 3.8 (interquartile range of 3.2 to 6.1), which encompasses the median value of the ratio of Flow Meter 2 to Flow Meter 1 of 3.4 reported above. Similarly, the ratio of E2003 to G2003 in the extratropics is 0.5 (0.5 to 0.7), and encompasses the median value of 0.5 .

Using the information described above as a proxy for calibration coefficients for the miscalibrated flow meters (i.e. Flow Meter 1 and Flow Meter 3), the mass concentrations derived from the teflon filters (i.e. G2003) were corrected. The statistics from the corrected mass concentrations are listed in Table 4, noting that values of OC and BC are nearly identical to those listed in Table 2 since the carbon aerosol mass concentrations were mainly derived using the properly calibrated flow meter (Flow Meter 2). $\mathrm{PM}_{2.5}, \mathrm{SO}_{4}$, and $\mathrm{NO}_{3}$ from G2003 agree to within 23\% with E2003 after we apply the proxy calibration correction, which is a $44 \%$ improvement over the pre-correction agreement. Equally as significant is the fact that the tropics to extratropics ratio of corrected mass concentrations (see end of Sect. 2.2) in Table 4 now agree to within $1 \%$ (a $57 \%$ improvement over pre-corrected 
Table 3. Results of simultaneous filter samples showing aerosol mass concentrations $\left(\mu \mathrm{g} / \mathrm{m}^{3}\right)$ determined using one of the three flow meters on the research aircraft. Flow Meter 2 had a reasonable calibration, while Flow Meters 1 and 3 were miscalibrated.

\begin{tabular}{lcccrc}
\hline flow meter ID & $\mathrm{PM}_{2.5}$ & $\mathrm{NO}_{3}$ & $\mathrm{SO}_{4}$ & $\mathrm{OC}$ & $\mathrm{BC}$ \\
\hline \multicolumn{7}{c}{ Test 1 } \\
Flow Meter 1 & 13.4 & 0.7 & 0.8 & 5.0 & 2.1 \\
Flow Meter 2 & 46.6 & 3.1 & 3.7 & 16.8 & 4.3 \\
\multicolumn{7}{c}{ Test 2 } & & & \\
Flow Meter 2 & 23.0 & 0.9 & 2.4 & 7.5 & 1.5 \\
Flow Meter 3 & 39.6 & 1.9 & 5.8 & 16.5 & 3.5 \\
\hline
\end{tabular}

values). Thus, after applying the proxy calibration correction, the mass concentrations derived from teflon and quartz filter samples can now be analyzed together with those reported by E2003. These corrected mass concentrations are what are referred to in the next sections.

The corrected mass concentrations listed in Table 4 affect some of the published results from past studies. K2003 results are not affected, and in fact their Table 1 includes the individual mass concentrations of $\mathrm{OC}$ and $\mathrm{BC}$ used in this study. G2003 presented results based on the relative contribution of $\mathrm{SO}_{4}$ and $\mathrm{NO}_{3}$ to $\mathrm{PM}_{2.5}$, but these numbers are consistent with those in this study since the same correction factor was applied to $\mathrm{SO}_{4}, \mathrm{NO}_{3}$, and $\mathrm{PM}_{2.5}$. Table 2 in $\mathrm{G} 2003$ lists mass concentrations from "Background Aerosol Samples", and Table 2 in Sinha et al. (2003b) lists mass concentrations for particulate matter from various "sectors". Coincidentally and conveniently, Table 2 in this study is consistent with Table 2 in both G2003 and Sinha et al. (2003b). Mass concentrations should be corrected to better match Table 4 in this study. Some of the various statements by Sinha et al. (2003b) would need to be revised to reflect the results of the correction, but most of their conclusions remain valid. Other studies do not appear to be affected.

\section{Results}

\section{1 $\mathbf{P M}_{2.5}$ aerosol mass}

The statistics of the speciated mass concentrations from all the filter samples (teflon, quartz, and those reported by E2003) are listed in Table 5. $\mathrm{PM}_{2.5}$ mass concentrations are about $12 \mu \mathrm{g} / \mathrm{m}^{3}$ in the extratropics and increase by a factor of four in the tropics to nearly $48 \mu \mathrm{g} / \mathrm{m}^{3}$. This increase is consistent with the data in Fig. 1 which shows that the tropics are where most of the burning occurs in August and September and with aerosol physical and optical properties listed in Table 1. The speciated mass apportionment reveals that the primary driving force for the increase in $\mathrm{PM}_{2.5}$ is an increase in $\mathrm{OC}$ and $\mathrm{BC}$ mass. $\mathrm{NO}_{3}$ mass increases by a factor of 14
Table 4. Comparison of median aerosol mass concentrations $\left(\mu \mathrm{g} / \mathrm{m}^{3}\right)$ and interquartile range (IQR) reported by Gao et al. (2003), G2003, and Kirchstetter et al. (2003), K2003, versus those reported by Eatough et al. (2003), E2003, for samples representative of Southern Hemisphere African (a) extratropics and (b) tropics after we applied corrections based on Table 3 .

\begin{tabular}{rrrrrr}
\hline & data source: & \multicolumn{2}{c}{ G2003 and K2003 } & \multicolumn{2}{c}{ E2003 } \\
\hline & species & median & IQR & median & IQR \\
\hline (a) & $\mathrm{PM}_{2.5}$ & 11.5 & $8.2-16.7$ & 14.0 & $8.7-27.4$ \\
& $\mathrm{OC}$ & 4.2 & $3.4-5.1$ & 3.5 & $3.4-9.3$ \\
& $\mathrm{BC}$ & 0.8 & $0.7-1.3$ & 0.9 & $0.5-1.8$ \\
& $\mathrm{SO}_{4}$ & 2.7 & $2.2-5.4$ & 4.0 & $1.8-6.5$ \\
$\mathrm{NO}_{3}$ & 0.2 & $0.2-0.3$ & 0.2 & $0.1-0.4$ \\
(b) & $\mathrm{PM}_{2.5}$ & 48.3 & $41.2-66.1$ & 43.7 & $31.1-63.6$ \\
& $\mathrm{OC}$ & 16.5 & $11.5-19.5$ & 23.2 & $17.1-36.2$ \\
& $\mathrm{BC}$ & 4.2 & $2.7-5.5$ & 1.8 & $1.4-1.8$ \\
& $\mathrm{SO}_{4}$ & 3.3 & $3.0-3.6$ & 7.7 & $5.7-8.1$ \\
$\mathrm{NO}_{3}$ & 2.4 & $1.5-3.0$ & 2.8 & $2.0-5.6$ \\
\hline
\end{tabular}

to a concentration of about $2.6 \mu \mathrm{g} / \mathrm{m}^{3}$. Although this $\mathrm{NO}_{3}$ mass concentration is greater than typical background concentrations reported by Sinha et al. (2003a) and Tripathi et al. (1996), $\mathrm{NO}_{3}$ still accounts for less than $5 \%$ of the $\mathrm{PM}_{2.5}$ mass.

Both $\mathrm{SO}_{4}$ and SVOC aerosol mass concentrations in Table 5 are not significantly different in the tropics compared to the extratropics. The similarity in $\mathrm{SO}_{4}$ could partly be attributed to additional $\mathrm{SO}_{4}$ sources in the extratropics that are not biomass burning in origin (Piketh et al., 1999; Bond et al., 2007). SVOC mass statistics are based on ten samples in the extratropics and four samples in the tropics, so the limited sample sizes may not be sufficient to support any conclusion about SVOC in the tropics versus the extratropics. The interquartile range of SVOC, for example, is much larger in the tropics, presumably indicating that the fire and/or biomass characteristics also were different among the four samples. The only conclusion in terms of SVOC that is offered in this study is exactly what E2003 pointed out: most filter samples do not include a measure of SVOC and therefore, based on Table 5, $\mathrm{PM}_{2.5}$ reported by $\mathrm{G} 2003$ and $\mathrm{K} 2003$ (and others using similar analysis techniques) may be underestimated by $11-33 \%$.

\section{2 $\quad \mathbf{P M}_{2.5}$ mass apportionment}

Using the information in Table 5, and converting the measured species to common molecular forms, the $\mathrm{PM}_{2.5}$ aerosol mass is apportioned into species contributions. The median values of the corrected mass concentrations of potassium $\left(\mathrm{K}^{+}\right)$by $\mathrm{G} 2003$ are 0.15 and $0.65 \mu \mathrm{g} / \mathrm{m}^{3}$ for the extratropics and tropics, respectively. This suggests that $94 \%$ (extratropics) and $86 \%$ (tropics) of the $\mathrm{SO}_{4}$ and $\mathrm{NO}_{3}$ ions are not 
Table 5. Mass concentrations $\left(\mu \mathrm{g} / \mathrm{m}^{3}\right)$ of $\mathrm{PM}_{2.5}$ and species contributing to $\mathrm{PM}_{2.5}\left(\mathrm{OC}, \mathrm{BC}, \mathrm{SO}_{4}, \mathrm{NO}_{3}\right.$, and $\left.\mathrm{SVOC}\right)$ samples representative of the extratropics and the tropics of Southern Hemisphere Africa. Statistics are presented as median and interquartile range (IQR). OM is calculated as $1.4^{*} \mathrm{OC}$ in the extratropics, and $2.1^{*} \mathrm{OC}$ in the tropics (see discussion in text).

\begin{tabular}{lrrrr}
\hline & \multicolumn{2}{c}{ extratropics } & \multicolumn{2}{c}{ tropics } \\
\hline species & median & IQR & median & IQR \\
\hline $\mathrm{PM}_{2.5}$ & 11.5 & $8.1-19.8$ & 47.5 & $38.3-66.5$ \\
$\mathrm{OC}$ & 3.9 & $3.4-5.3$ & 17.1 & $12.0-22.6$ \\
$\mathrm{BC}$ & 0.9 & $0.6-1.3$ & 3.4 & $1.8-4.5$ \\
$\mathrm{SO}_{4}$ & 3.7 & $2.2-6.1$ & 3.4 & $3.1-3.8$ \\
$\mathrm{NO}_{3}$ & 0.2 & $0.1-0.3$ & 2.6 & $1.5-3.0$ \\
$\mathrm{SVOC}$ & 5.6 & $3.2-8.7$ & 5.7 & $5.7-50.5$ \\
$\mathrm{OM}$ & 5.3 & $4.6-7.2$ & 36.0 & $25.3-47.7$ \\
\hline
\end{tabular}

balanced by $\mathrm{K}^{+}$, and it is assumed for simplicity that they are entirely neutralized by ammonium $\left(\mathrm{NH}_{4}{ }^{+}\right)$. The ionic aerosol species $\left(\mathrm{SO}_{4}\right.$ and $\left.\mathrm{NO}_{3}\right)$ are converted to ammonium sulfate $\left(\left(\mathrm{NH}_{4}\right)_{2} \mathrm{SO}_{4}\right)$ and ammonium nitrate $\left(\mathrm{NH}_{4} \mathrm{NO}_{3}\right)$ by multiplying the mass of $\mathrm{SO}_{4}$ and $\mathrm{NO}_{3}$ by 1.38 and 1.29 , respectively.

Conversion of $\mathrm{OC}$ to organic matter (OM) to account for the non-carbon mass of molecular forms of $\mathrm{OC}$ is subject to considerable uncertainty. Dentener et al. (2006) suggest a conversion factor of 1.4. Turpin and Lim (2001) suggest that 1.4 should be considered a lower bound to estimates and that a value of $1.6 \pm 0.2$ and $2.1 \pm 0.2$ are more representative of urban and non-urban aerosols, respectively, but they point out that even this range is subject to re-examination considering how little we still understand about the many compounds that together comprise "OC" (e.g. Kanakidou et al., 2005). A $\mathrm{OM} / \mathrm{OC}$ ratio for the extratropics and tropics is derived by assuming that $100 \%$ of the $\mathrm{PM}_{2.5}$ mass can be attributed to $\mathrm{NH}_{4} \mathrm{NO}_{3},\left(\mathrm{NH}_{4}\right)_{2} \mathrm{SO}_{4}, \mathrm{BC}$, and $\mathrm{OM}$ (including SVOC makes no difference in this case). Thus, $\mathrm{OM} / \mathrm{OC}=\left(\mathrm{PM}_{2.5^{-}}\right.$ $\left.\mathrm{NH}_{4} \mathrm{NO}_{3}-\left(\mathrm{NH}_{4}\right)_{2} \mathrm{SO}_{4}-\mathrm{BC}\right) / \mathrm{OC}$. This gives a value of 1.4 (interquartile range is 1.0 to 1.6 ) for $\mathrm{OM} / \mathrm{OC}$ in the extratropics and 2.1 (1.6 to 3.0) for OM/OC in the tropics. The median values are within the broad range of 1.4-2.3 suggested above.

The chemical apportionment of $\mathrm{PM}_{2.5}$ mass is shown in Fig. 2 In the extratropics, $54 \%$ of the aerosol mass is OM and $\mathrm{BC}$, while the remaining $46 \%$ is comprised of $\mathrm{NH}_{4} \mathrm{NO}_{3}$ and $\left(\mathrm{NH}_{4}\right)_{2} \mathrm{SO}_{4}$. As discussed above, $\left(\mathrm{NH}_{4}\right)_{2} \mathrm{SO}_{4}$ is roughly the same in the tropics and the extratropics, but the dramatic increase in $\mathrm{OM}$ and $\mathrm{BC}$ in the tropics results in an aerosol comprised of $83 \%$ carbonaceous components. If SVOC is included, the contribution of carbonaceous particles to $\mathrm{PM}_{2.5}$ mass increases to $69 \%$ in the extratropics and $85 \%$ in the tropics.

\subsection{Aerosol optical depth apportionment}

In this Section, the apportionment of AOD at a wavelength of $550 \mathrm{~nm}$ is described. Most of the speciated aerosol mass concentrations that comprise the median values listed in Table 5 were coincident with measurements of SCA and ABS (with a $\mathrm{PM}_{2.5}$ aerosol cut-off) at a "dry" relative humidity (RH) of 30\% (see Magi et al., 2003, 2008 for details about the measurements of SCA and ABS). Aerosol mass concentrations in this study are reported at standard temperature and pressure (STP, $273 \mathrm{~K}, 1013 \mathrm{hPa}$ ) and for dry aerosol mass, so the dry SCA and ABS are also adjusted to STP. Thus, the species mass concentrations can be related to SCA and ABS by assuming that each species plays independent roles (i.e. an external mixture) in determining the totals by

$\mathrm{SCA}=\sum_{i=1}^{4} M_{i} * \mathrm{MSC}_{i}$

$\mathrm{ABS}=\sum_{i=1}^{4} M_{i} * \mathrm{MAC}_{i}$

where $M_{i}$ is the mass concentration of $\mathrm{NH}_{4} \mathrm{NO}_{3}$, $\left(\mathrm{NH}_{4}\right)_{2} \mathrm{SO}_{4}, \mathrm{OM}$, and $\mathrm{BC}$ and $\mathrm{MSC}_{i}$ and $\mathrm{MAC}_{i}$ are the mass scattering and mass absorption cross sections (e.g. Bond and Bergstrom, 2006), in units of $\mathrm{m}^{2} / \mathrm{g}$. SCA and ABS in these equations and those that follow are at a dry $\mathrm{RH}$ and at STP.

All the aerosol species contribute to scattering. For the multiple linear regression, the mass concentrations of $\mathrm{NH}_{4} \mathrm{NO}_{3}$ and $\left(\mathrm{NH}_{4}\right)_{2} \mathrm{SO}_{4}$ are combined together and $\mathrm{OM}$ and $\mathrm{BC}$ are also combined together, such that we modify Eq. (1) to be

$\mathrm{SCA}=M_{\text {ionic }} * \mathrm{MSC}_{\text {ionic }}+M_{\text {carbon }} * \mathrm{MSC}_{\text {carbon }}$

where $M_{\text {ionic }}$ is the sum of $\mathrm{NH}_{4} \mathrm{NO}_{3}$ and $\left(\mathrm{NH}_{4}\right)_{2} \mathrm{SO}_{4}$ and $M_{\text {carbon }}$ is the sum of OM and BC. The regression is unstable if the four aerosol species are separately considered, mainly due to the relatively small sample size. Since all the scattering is attributed to these aerosol species, it is also important to consider the molecular forms of the species (i.e. $\mathrm{NH}_{4} \mathrm{NO}_{3}$, $\left(\mathrm{NH}_{4}\right)_{2} \mathrm{SO}_{4}$, and $\mathrm{OM}$ as opposed to $\mathrm{NO}_{3}, \mathrm{SO}_{4}$, and $\mathrm{OC}$ ). The values of $M_{\text {ionic }}$ and $M_{\text {carbon }}$ are then partitioned using Mie theory (Bohren and Huffman, 1983; Mätzler, 2002; Bond et al., 2006; http://www.hiwater.org/) approximations to derive MSC $\mathrm{OC}_{\mathrm{C}}, \mathrm{MSC}_{\mathrm{BC}}, \mathrm{MSC}_{\mathrm{SO}_{4}}$, and $\mathrm{MSC}_{\mathrm{NO}_{3}}$.

Equation (2) can be simplified since $\mathrm{NH}_{4} \mathrm{NO}_{3}$ and $\left(\mathrm{NH}_{4}\right)_{2} \mathrm{SO}_{4}$ do not significantly absorb visible radiation (e.g. Tang and Munkelwitz, 1994), while BC and OC are both potential absorbers (e.g. Bond and Bergstrom, 2006; Kirchstetter et al., 2004). Therefore Eq. (2) becomes 
a. extratropics

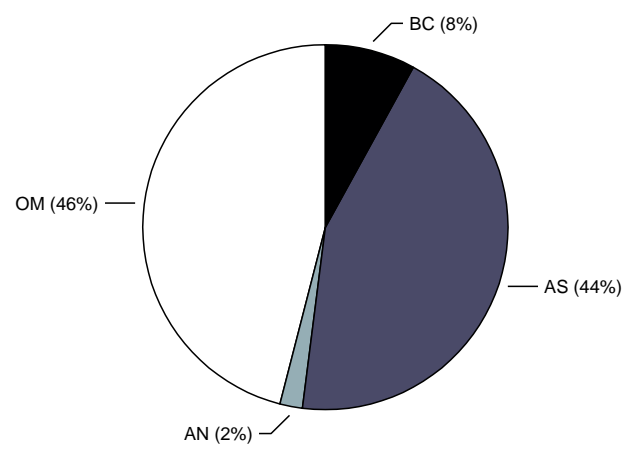

b. tropics

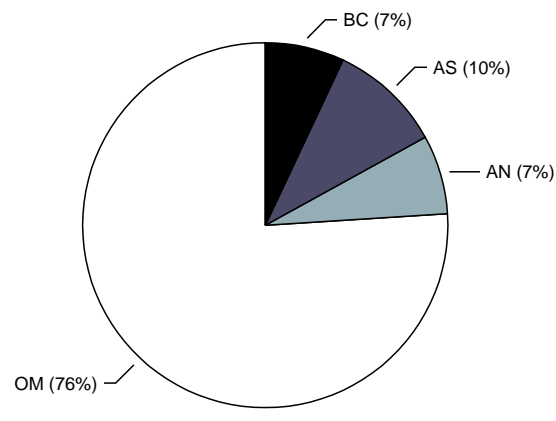

Fig. 2. Apportionment of $\mathrm{PM}_{2.5}$ aerosol mass concentrations for (a) extratropical southern Africa and (b) tropical southern Africa. Shown are the median percent contributions of organic matter (OM), black carbon (BC), ammonium nitrate (AN), and ammonium sulfate (AS).

$\mathrm{ABS}=M_{\mathrm{OC}} * \mathrm{MAC}_{\mathrm{OC}}+M_{\mathrm{BC}} * \mathrm{MAC}_{\mathrm{BC}}$

noting that $\mathrm{BC}$ is the major absorbing aerosol species in the mid-visible, while $\mathrm{OC}$ absorption seems to vary depending on the location. Kirchstetter et al. (2004) showed that OC accounts for about $7-24 \%$ of the total absorption at a wavelength of $550 \mathrm{~nm}$, with an imaginary refractive index of about 0.03. Kanakidou et al. (2005) summarized research about $\mathrm{OC}$ and suggested an imaginary refractive index for OC of about 0.006 . Transport models discussed by Kinne et al. (2006) assumed an imaginary refractive index of 0.03 , similar to Kirchstetter et al. (2004). Even a very small OC contribution to total absorption is important, however, since OC mass burden is often much greater than $\mathrm{BC}$ mass burden (e.g. Bond et al., 2004).

The values for MSC and MAC, determined by solving Eqs. (3) and (4) using multiple linear regression, are listed in Table 6 along with the standard errors. Also listed in Table 6 are MSC and MAC calculated from Mie theory (Bohren and Huffman, 1983; Mätzler, 2002; Bond et al., 2006; http://www.hiwater.org/), where the assumptions used to calculate the theoretical MSC and MAC are listed in Table 7 (lognormal size distribution diameter and standard deviation, density, and refractive indices at $550 \mathrm{~nm}$ ). The values in Table 7 for OC are similar to those used in models (e.g. Kinne et al., 2006) and suggested in the review study by Kanakidou et al. (2005), while the density of OC is based on Turpin and Lim (2001). The values for BC are based on Kirchstetter et al. (2004) and Bond and Bergstrom (2006). The values we used to simulate $\mathrm{NH}_{4} \mathrm{NO}_{3}$ and $\left(\mathrm{NH}_{4}\right)_{2} \mathrm{SO}_{4}$ are based on Tang and Munkelwitz (1994).

Values of $\mathrm{MSC}_{\mathrm{OC}}, \mathrm{MSC}_{\mathrm{BC}}, \mathrm{MSC}_{\mathrm{SO}_{4}}$, and $\mathrm{MSC}_{\mathrm{NO}_{3}}$ are derived by partitioning the values of $\mathrm{MSC}_{\text {ionic }}$ and $\mathrm{MSC}_{\text {carbon }}$ from Eq. (3) according to the theoretical contributions predicted by Mie theory. Thus $\mathrm{MSC}_{\mathrm{SO}_{4}}=0.47 * 1.38 * \mathrm{MSC}_{\text {ionic }}$ and $\mathrm{MSC}_{\mathrm{NO}_{3}}=0.53 * 1.29 * \mathrm{MSC}_{\text {ionic }}$, where the 0.47 and 0.53 are the fractional contributions to $\mathrm{MSC}_{\text {ionic }}$ and 1.38 and 1.29 are the molecular conversion factors.
Table 6. The mass scattering cross sections for organic carbon $\left(\mathrm{MSC}_{\mathrm{OC}}\right)$, black carbon $\left(\mathrm{MSC}_{\mathrm{BC}}\right)$, sulfate $\left(\mathrm{MSC}_{\mathrm{SO}_{4}}\right)$, and nitrate $\left(\mathrm{MSC}_{\mathrm{NO}_{3}}\right)$ and the mass absorption cross sections for organic carbon $\left(\mathrm{MAC} \mathrm{OC}_{\mathrm{OC}}\right.$ ) and black carbon $\left(\mathrm{MAC}_{\mathrm{BC}}\right)$, as derived from measurements and from Mie theory. The units are $\mathrm{m}^{2} / \mathrm{g}$ and MSC and MAC are at a wavelength of $550 \mathrm{~nm}$.

\begin{tabular}{|c|c|c|}
\hline & measurements & Mie \\
\hline $\mathrm{MSC}_{\mathrm{OC}}$ & $3.9 \pm 0.6$ & 3.7 \\
\hline $\mathrm{MSC}_{\mathrm{BC}}$ & $1.6 \pm 0.2$ & 1.5 \\
\hline $\mathrm{MSC}_{\mathrm{SO}_{4}}$ & $0.6 \pm 0.8$ & 0.3 \\
\hline $\mathrm{MSC}_{\mathrm{NO}_{3}}$ & $0.6 \pm 0.8$ & 0.4 \\
\hline $\mathrm{MAC}_{\mathrm{OC}}$ & $0.7 \pm 0.6$ & 0.6 \\
\hline $\mathrm{MAC}_{\mathrm{BC}}$ & $8.2 \pm 1.1$ & 7.9 \\
\hline
\end{tabular}

From $\mathrm{MSC}_{\text {carbon }}, \quad \mathrm{MSC}_{\mathrm{OC}}=0.59 * 1.7 * \mathrm{MSC}_{\text {carbon }}$ and $\mathrm{MSC}_{\mathrm{BC}}=0.41 * \mathrm{MSC}_{\text {carbon, }}$, where 0.59 and 0.41 are the fractional contributions to $\mathrm{MSC}_{\text {carbon }}$ and 1.7 is the mean ratio of OM to OC. In all cases, using literature-based assumptions to simulate the aerosol components, the measurement-based MSC and MAC agree with theoretical values of MSC and MAC. These results are analyzed in the next Section.

\section{Analysis}

\subsection{Aerosol mass}

The evidence presented above clearly shows that the more concentrated burning in tropical southern Africa results in an aerosol that is significantly different than extratropical southern Africa. These differences apply to aerosol optical properties and number concentrations (Table 1), $\mathrm{PM}_{2.5}$ mass concentrations (Table 5), and even $\mathrm{PM}_{2.5}$ mass apportionment (Fig. 2). The major differences are that tropical southern African aerosol is composed of $83 \%$ carbonaceous aerosol, 
Table 7. Aerosol characteristics used to calculate Mie mass scattering cross section and mass absorption cross section. The geometric mean diameter $\left(D_{g}\right)$ and geometric standard deviation $\left(\sigma_{g}\right)$ describe the lognormal aerosol size distribution. The real and imaginary refractive indices ( $m_{\text {real }}$ and $\left.m_{\text {imag }}\right)$ are at a wavelength of $550 \mathrm{~nm}$.

\begin{tabular}{lrrrrr}
\hline species & $D_{g}(\mathrm{~nm})$ & $\sigma_{g}$ & $\begin{array}{r}\text { density } \\
\left(\mathrm{g} / \mathrm{cm}^{3}\right)\end{array}$ & $m_{\text {real }}$ & $m_{\text {imag }}$ \\
\hline $\mathrm{OC}$ & 150 & 2.0 & 1.40 & 1.50 & 0.03 \\
$\mathrm{BC}$ & 35 & 1.8 & 1.35 & 1.85 & 0.72 \\
$\left(\mathrm{NH}_{4}\right)_{2} \mathrm{SO}_{4}$ & 50 & 1.5 & 1.80 & 1.53 & $10^{-7}$ \\
$\mathrm{NH}_{4} \mathrm{NO}_{3}$ & 50 & 1.5 & 1.80 & 1.56 & $10^{-9}$ \\
\hline
\end{tabular}

while the extratropical southern African aerosol is composed of $54 \%$ carbonaceous aerosol and $\mathrm{PM}_{2.5}$ mass increases by a factor of four in the tropical aerosol due mainly to increases in OC mass. The extratropical aerosol samples discussed in this study are most likely biased towards the more intense biomass burning since the sample locations (Fig. 1) are located east of the Namib and Kalahari deserts. Sulfate aerosol contributions from industrial sources in northeast South Africa (e.g. Bond et al., 2007; Piketh et al., 1999) may also affect the mass apportionment we showed in Fig. 2a. The fractional contributions to overall $\mathrm{PM}_{2.5}$ mass should be considered when simulating the aerosol over southern Africa.

Formenti et al. (2003) characterized southern African aerosol properties near Namibia $\left(15-25^{\circ} \mathrm{S}, 10-15^{\circ} \mathrm{E}\right)$ during SAFARI-2000. Using their reported values of $\mathrm{NH}_{4} \mathrm{NO}_{3}$, $\left(\mathrm{NH}_{4}\right)_{2} \mathrm{SO}_{4}, \mathrm{OM}$, and $\mathrm{BC}$ mass concentrations, carbonaceous aerosol makes up about $70-90 \%$ of $\mathrm{PM}_{2.5}$ mass. Even considering all of the reported species in Formenti et al. (2003), $\mathrm{PM}_{2.5}$ aerosol is composed of about $60-75 \%$ carbonaceous aerosol. Although the samples discussed by Formenti et al. (2003) are west and south of major burning regions, particles emitted from biomass burning are often transported from both tropical and extratropical burning regions over Namibia and over the southeast Atlantic Ocean (e.g. Garstang et al., 1996). Formenti et al. (2003) also confirmed this transport pathway with an analysis of backtrajectories of their sample locations.

The mass concentrations of $\mathrm{NO}_{3}, \mathrm{SO}_{4}, \mathrm{OC}$, and $\mathrm{BC}$ reported by Formenti et al. (2003) range from 1.0-1.4, 1.9$2.0,6-20$, and $1.0-2.0 \mu \mathrm{g} / \mathrm{m}^{3}$, respectively. Values of $\mathrm{NO}_{3}$, $\mathrm{OC}$, and $\mathrm{BC}$ in Table 5 are all very similar, while $\mathrm{SO}_{4}$ mass concentration is a factor of two larger. The higher $\mathrm{SO}_{4}$ concentration is expected since many of samples in this study were affected by proximity to concentrated burning (tropics) or proximity to industrial sources (extratropics).

Ruellan et al. (1999) collected aircraft-based in situ aerosol samples during the Experiment for Regional Sources and Sinks of Oxidants (EXPRESSO) field campaign in November and December 1996 over Northern Hemisphere equatorial Africa $\left(3-5^{\circ} \mathrm{N}, 17-19^{\circ} \mathrm{E}\right)$. Fires in this region in November and December are as numerous as those in tropical southern Africa during August and September, so there should be some similarities in the aerosol regardless of the differences in burning characteristics (i.e. vegetation, combustion completeness). Ruellan et al. (1999) reported mean $\mathrm{OC}$ and BC mass concentrations of about $22 \pm 11$ and $5 \pm 2 \mu \mathrm{g} / \mathrm{m}^{3}$, respectively, between the surface and about $4 \mathrm{~km}$. This is very similar to median OC and BC mass concentrations of $17 \mu \mathrm{g} / \mathrm{m}^{3}\left(12-23 \mu \mathrm{g} / \mathrm{m}^{3}\right.$ interquartile range) and $3.4 \mu \mathrm{g} / \mathrm{m}^{3}\left(1.8-4.5 \mu \mathrm{g} / \mathrm{m}^{3}\right.$ interquartile range), respectively, reported in Table 5 for tropical southern Africa.

Across the entire African region, there is variability in aerosol mass concentration in the polluted layer, but the magnitudes generally agree in terms of carbonaceous aerosol. Based on a small number of studies from EXPRESSO and SAFARI-2000, the carbonaceous aerosol mass concentration seems to decrease from north to south and from east to west. This is consistent with fire occurrence patterns derived from MODIS (Giglio et al., 2003, 2006). Both this study, which is based on data originally described by E2003, G2003, and K2003, and the study by Formenti et al. (2003), suggest that at least half the $\mathrm{PM}_{2.5}$ aerosol mass concentration during the biomass burning season is composed of carbonaceous aerosol. This fraction increases significantly as $\mathrm{PM}_{2.5}$ mass increases.

The correlation of $\mathrm{OC}, \mathrm{BC}, \mathrm{NO}_{3}$, and $\mathrm{SO}_{4}$ mass with $\mathrm{PM}_{2.5}$ mass is shown in Fig. 3 and, with the exception of $\mathrm{SO}_{4}$, all are significantly correlated ( $\mathrm{p}$ values less than 0.05 , implying the correlation is significant with greater than $95 \%$ confidence). $\mathrm{OC}$ is clearly the main factor driving increases in $\mathrm{PM}_{2.5}$ mass, with $r^{2}=0.87 . \mathrm{SO}_{4}$ on the other hand is not significantly correlated, and only about $7 \%$ of the variance in $\mathrm{PM}_{2.5}$ can be explained by $\mathrm{SO}_{4}$.

The significant correlations of $\mathrm{OC}$ and $\mathrm{BC}$ mass with $\mathrm{PM}_{2.5}$ mass is not restricted to the tropics or the extratropics. The correlation of $\mathrm{NO}_{3}$ and $\mathrm{SO}_{4}$ with $\mathrm{PM}_{2.5}$, however, does depend on the regional subset. Namely, $\mathrm{SO}_{4}$ is significantly correlated with $\mathrm{PM}_{2.5}$ in the extratropics $\left(r^{2}=0.67\right)$, and $\mathrm{NO}_{3}$ is significantly correlated with $\mathrm{PM}_{2.5}$ in the tropics $\left(r^{2}=0.60\right)$, while the opposite in both cases is not true. The better correlation of $\mathrm{NO}_{3}$ with $\mathrm{PM}_{2.5}$ in the tropics, where burning is more prevalent, agrees with Hobbs et al. (2003), who suggested $\mathrm{NO}_{3}$ enhancements in aged smoke due to secondary (photochemical) formation. The evidence presented in this study suggests that the major $\mathrm{SO}_{4}$ sources in the extratropics are split between biomass burning and fossil fuel burning in northeastern South Africa and that this explains why $\mathrm{SO}_{4}$ is better correlated with $\mathrm{PM}_{2.5}$ in the extratropics than the tropics.

\subsection{Mass scattering and mass absorption cross sections}

The unifying characteristics of the tropical and extratropical southern Africa aerosol are the values of MSC and MAC, 
especially with respect to carbon species (OC and $\mathrm{BC}$ ). Using the multiple linear regression technique described in Sect. 3.3, $\mathrm{MSC}_{\mathrm{OC}}=3.9 \pm 0.6 \mathrm{~m}^{2} / \mathrm{g}$ and $\mathrm{MSC}_{\mathrm{BC}}=1.6 \pm 0.2 \mathrm{~m}^{2} / \mathrm{g}$ (Table 6). Based on previous work, all the absorption was assumed to be attributed to $\mathrm{OC}$ and $\mathrm{BC}$, and the multiple linear regression results suggested $\mathrm{MAC}_{\mathrm{OC}}=0.7 \pm 0.6 \mathrm{~m}^{2} / \mathrm{g}$ and $\mathrm{MAC}_{\mathrm{BC}}=8.2 \pm 1.1 \mathrm{~m} / \mathrm{g}$ (Table 6). $\mathrm{MSC}_{\mathrm{SO}_{4}}$ and $\mathrm{MSC}_{\mathrm{NO}_{3}}$ are both very small and the uncertainty in the multiple linear regression coefficients is large. All of the measurement-based results in this study, however, are consistent with Mie theory, although the theoretical values are themselves dependent on assumptions listed in Table 7.

In a detailed review of past research related to $\mathrm{BC}$ absorption and a critical analysis of $\mathrm{BC}$ absorption by Bond and Bergstrom (2006), they suggested that $\mathrm{MSC}_{\mathrm{BC}}$ varied from about 1.6 to $3.7 \mathrm{~m}^{2} / \mathrm{g}$ and $\mathrm{MAC}_{\mathrm{BC}}=7.5 \pm 1.2 \mathrm{~m}^{2} / \mathrm{g}$. Values of $\mathrm{MSC}_{\mathrm{BC}}$ and $\mathrm{MAC}_{\mathrm{BC}}$ listed in Table 6 agree to within uncertainty with Bond and Bergstrom (2006). OC optical properties, particularly absorption, are a much more poorly understood aspect of aerosol science. Kirchstetter et al. (2004) derived a value of $\mathrm{MAC}_{\mathrm{OC}}=0.6 \mathrm{~m}^{2} / \mathrm{g}$ from smoke samples collected during SAFARI-2000, while Sun et al. (2007) suggest $\mathrm{MAC}_{\mathrm{OC}}=1.0 \mathrm{~m}^{2} / \mathrm{g}$ based on a theoretical model of a combustion aerosol. The value of $0.7 \pm 0.6 \mathrm{~m}^{2} / \mathrm{g}$ in this study agrees well with these past studies, especially considering the much different methodologies. The value of $\mathrm{MSC}_{\mathrm{OC}}$ listed in Table 6 is on the high end of previously published values of $\mathrm{MSC}_{\mathrm{OC}}$, which range from $1-5 \mathrm{~m}^{2} / \mathrm{g}$ and are sometimes based on data, and sometimes based on assumptions (e.g. White, 1990; Liousse et al., 1996; Magi et al., 2009).

The single scattering albedo (SSA) at $550 \mathrm{~nm}$ is defined as MSC/MEC where MEC is the mass extinction cross section and is the sum of MSC and MAC. MSC/MEC and SCA/EXT as described in Sect. 2.1 are equivalent ways of calculating SSA. $\mathrm{SSA}_{\mathrm{SO}_{4}}$ and $\mathrm{SSA}_{\mathrm{NO}_{3}}$ are therefore equal to 1 in this study, but $\mathrm{SSA}_{\mathrm{OC}}=0.85$ and $\mathrm{SSA}_{\mathrm{BC}}=0.17$. Bond and Bergstrom (2006) suggest that $\mathrm{SSA}_{\mathrm{BC}}=0.2-0.3$, so the derived value in this study is at the low end of that range. In a modeling study, Magi et al. (2009) suggested $\mathrm{SSA}_{\mathrm{OC}}=0.97$ and $\mathrm{SSA}_{\mathrm{BC}}=0.21$, but also showed that the overall aerosol SSA simulated by the model was biased high compared to measurements. The high biases in modeled SSA (e.g. Kinne et al., 2006) would improve if models simulated a more strongly absorbing OC component in regions of the world impacted by biomass burning, as the data presented here suggests.

\subsection{Apportionment of scattering and absorption}

Using the MSC and MAC derived from multiple linear regression, the scattering and absorption in the extratropics and the tropics is apportioned. In the apportionment, the molecular forms of the species are used for scattering since all the aerosol mass is responsible for scattering solar radiation. For
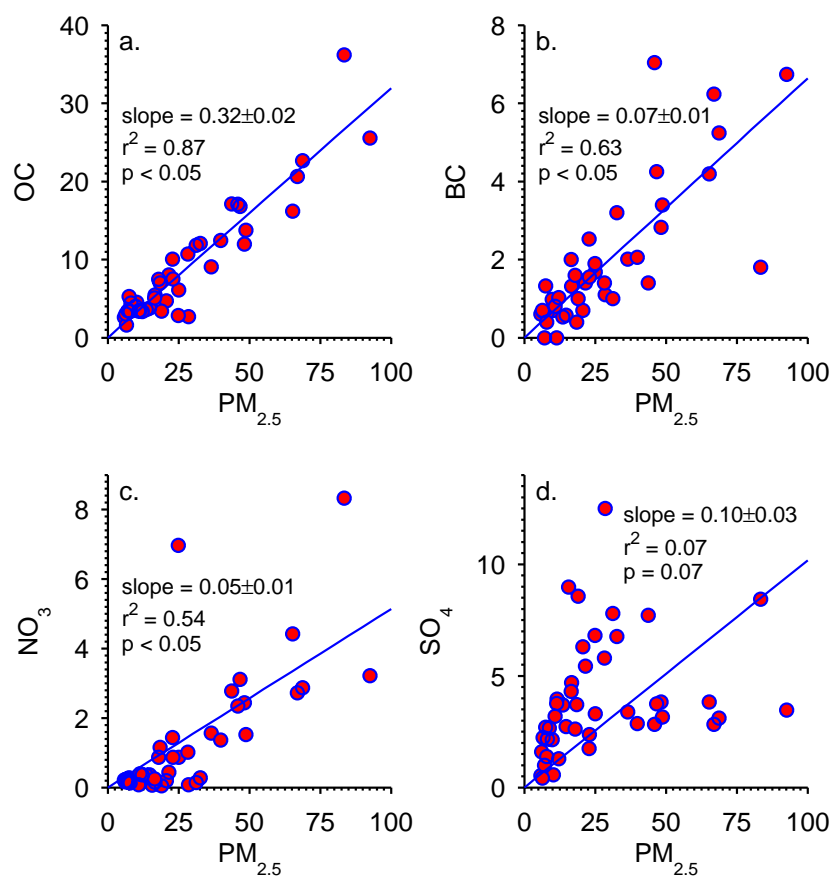

Fig. 3. Correlation of mass concentrations $\left(\mu \mathrm{g} / \mathrm{m}^{3}\right)$ of (a) organic carbon (OC), (b) black carbon (BC), (c) nitrate ions $\left(\mathrm{NO}_{3}\right)$, and (d) sulfate ions $\left(\mathrm{SO}_{4}\right)$ with particulate matter with diameters less than $2.5 \mu \mathrm{m}\left(\mathrm{PM}_{2.5}\right)$. Listed in the figures are the slopes and 95\% confidence interval of the linear regression, the correlation coefficients $\left(r^{2}\right)$, and the p-values $(p)$ of the correlation.

absorption, $\mathrm{OC}$ and $\mathrm{BC}$ are used since there is no evidence suggesting that $\mathrm{OM}$ is more absorbing than $\mathrm{OC}$.

The aerosol optical properties apportionment for the extratropics is shown in Fig. 4 while the tropical apportionment is shown in Fig. 5. Both figures reveal similar trends, but $\mathrm{NH}_{4} \mathrm{NO}_{3}$ and $\left(\mathrm{NH}_{4}\right)_{2} \mathrm{SO}_{4}$ account for about twice as much scattering in the extratropics than in the tropics. Carbonaceous aerosol accounts for an overwhelming $80-90 \%$ of the total scattering.

The evidence presented in Figs. $4 \mathrm{~b}$ and $5 \mathrm{~b}$ suggests that OC accounts for about 26-27\% of the absorption, while $\mathrm{BC}$ accounts for the remainder. These numbers agree with SAFARI-2000 results by Kirchstetter et al. (2004), who used a much different methodology and showed that OC accounts for $7-24 \%$ of the absorption at $550 \mathrm{~nm}$ for freshly emitted smoke. Although the differences between Kirchstetter et al. (2004) and this study are not statistically significant, the generally higher contribution of $\mathrm{OC}$ to absorption in this study might be due to enhanced OC absorption from secondary particle formation as the smoke ages in the atmosphere. In terms of the scales involved in simulating an aerosol in climate models, it is perhaps more appropriate to model the properties of an aged aerosol. 
b. absorption

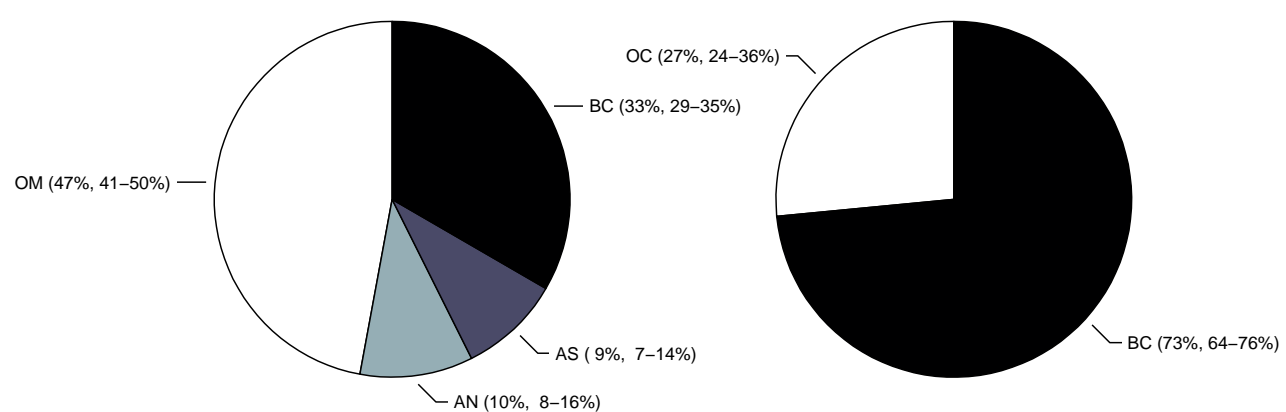

Fig. 4. Apportionment of (a) scattering and (b) absorption at a wavelength of $550 \mathrm{~nm}$ in extratropical southern Africa. Shown are the median percent contributions (with the interquartile range) of organic matter $(\mathrm{OM})$, black carbon $(\mathrm{BC})$, ammonium nitrate (AN), and ammonium sulfate (AS).
a. scattering
b. absorption

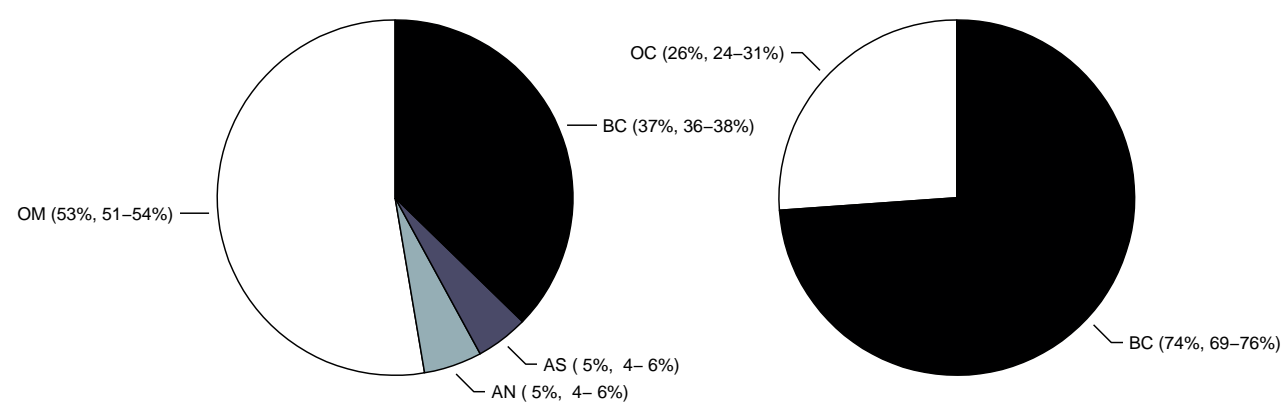

Fig. 5. Apportionment of (a) scattering and (b) absorption at a wavelength of $550 \mathrm{~nm}$ in tropical southern Africa. Shown are the median percent contributions (with the interquartile range) of organic matter $(\mathrm{OM})$, black carbon $(\mathrm{BC})$, ammonium nitrate (AN), and ammonium sulfate (AS).

\section{Conclusions}

Using synthesized results from three previously published studies, the southern African aerosol during the biomass burning season was characterized. The synthesis provided speciated aerosol mass representative of tropical and extratropical southern Africa. $\mathrm{PM}_{2.5}$ mass in the tropics is a factor of four greater than in the extratropics (Table 5), and this is driven primarily by increases in carbonaceous aerosol mass from the more widespread occurrence of fires in the tropics. The magnitude and species contributions to total aerosol mass in this study (Fig. 2), after applying corrections described in Sect. 2, agree well with other studies of African aerosols dominated by biomass burning (Ruellan et al., 1999; Formenti et al., 2003). Using aerosol mass concentrations together with measurements of aerosol optical properties (Magi et al., 2008), mass scattering cross sections (MSC) and mass absorption cross sections (MAC) for the aerosol species were derived. The measurement-based MSC and MAC for carbonaceous aerosol species (Table 6) all agreed with theoretical values of MSC and MAC predicted by Mie theory and with literature-based values.

The results presented in this study support the theory that the organic carbon (OC) component of an aerosol dominated by biomass burning particles absorbs a significant fraction of visible radiation. Climate models rely on a variety of assumptions about the basic properties (size, composition, refractive index, mixing state) of black carbon (BC) that are inconsistent with recent research (Bond and Bergstrom, 2006), and recent results (e.g. Kirchstetter et al., 2004) suggest the same is true for OC. As shown in this study, carbonaceous aerosol mass accounts for $54-83 \%$ of the aerosol mass over southern Africa, so assumptions about BC and $\mathrm{OC}$ are particularly important over biomass burning regions. The results presented here support the findings of Bond and Bergstrom (2006) regarding BC and those by Kirchstetter et al. (2004) for OC.

Wild (2008) points out that climate models contributing to the IPCC 4th Assessment Report do not adequately account for absorbing aerosol, and most (see Meehl et al., 2007) do 
not even include $\mathrm{OC}$ and $\mathrm{BC}$ as forcing agents in climate simulations. Of the IPCC models that do include OC and BC, only the NASA GISS model (Liu et al., 2006) uses a treatment of $\mathrm{OC}$ absorption that is consistent with results by Kirchstetter et al. (2004). Both the NOAA GFDL (Magi et al., 2009) and the MPI ECHAM5-HAM (Stier et al., 2005) models use imaginary refractive indices for OC that are about five times less than suggested by current measurement-based results (Kirchstetter et al., 2004). The implications of more strongly absorbing OC on global and regional climate needs to be investigated, but as Wild (2008) showed, it is clear that the surface radiation budget cannot be properly simulated until we better understand basic aerosol properties and assimilate this understanding into climate models.

Models need to examine both the assumed properties of carbonaceous aerosol species and the subsequent mass apportionment in biomass burning regions to fully understand any discrepancies (e.g. Liu et al., 2006; Magi et al., 2009) that may exist. Results in this study will improve the understanding of both of these issues. In future work, the wavelength dependence of the mass scattering and mass absorption cross sections over southern Africa for the major aerosol species simulated in climate models will be discussed. This will provide further constraint on assumptions required by models to simulate the biomass burning component of the global aerosol.

Acknowledgements. Thank you to Delbert Eatough, Song Gao, and Tom Kirchstetter for the data discussed in this study. I thank Tom Kirchstetter and Song Gao for useful and supportive comments on this paper, as well as two anonymous referees for their constructive comments.

Edited by: T. Kirchstetter

\section{References}

Bohren, C. F. and Huffman, D. R.: Absorption and scattering of light by small particles, John Wiley and Sons, New York, 1983.

Bond, T. C., Streets, D. G., Yarber, K. F., Nelson, S. M., Woo, J., and Klimont, Z.: A technology-based global inventory of black and organic carbon emissions from combustion, J. Geophys. Res., 109, D14203, doi:10.1029/2003JD003697, 2004.

Bond, T. C. and Bergstrom, R. W.: Light Absorption by Carbonaceous Particles: An Investigative Review, Aerosol Sci. Tech., 40, 27-67, 2006.

Bond, T. C., Habib, G., and Bergstrom, R. W.: Limitations in the enhancement of visible light absorption due to mixing state, J. Geophys. Res., 111, D20211, doi:10.1029/2006JD007315, 2006.

Bond, T. C., Bhardwaj, E., Dong, R., Jogani, R., Jung, S., Roden, C., Streets, D. G., and Trautmann, N. M.: Historical emissions of black and organic carbon aerosol from energy-related combustion, 1850-2000, Glob. Biogeochem. Cyc., 21, GB2018, doi:10.1029/2006GB002840, 2007.

Dentener, F., Kinne, S., Bond, T., Boucher, O., Cofala, J., Generoso, S., Ginoux, P., Gong, S., Hoelzemann, J. J., Ito, A., Marelli, L., Penner, J. E., Putaud, J.-P., Textor, C., Schulz, M., van der Werf,
G. R., and Wilson, J.: Emissions of primary aerosol and precursor gases in the years 2000 and 1750 prescribed data-sets for AeroCom, Atmos. Chem. Phys., 6, 4321-4344, 2006, http://www.atmos-chem-phys.net/6/4321/2006/.

Eatough, D. J., Eatough, N. L., Pang, Y., Sizemore, S., Kirchstetter, T. W., Novakov, T., and Hobbs, P. V.: Semivolatile particulate organic material in southern Africa during SAFARI 2000, J. Geophys. Res., 108(D13), 8479, doi:10.1029/2002JD002296, 2003.

Formenti, P., Elbert, W., Maenhaut, W., Haywood, J., Osborne, S., and Andreae, M. O.: Inorganic and carbonaceous aerosols during the Southern African Regional Science Initiative (SAFARI 2000) experiment: Chemical characteristics, physical properties, and emission data for smoke from African biomass burning, J. Geophys. Res., 108(D13), 8488, doi:10.1029/2002JD002408, 2003.

Gao, S., Hegg, D. A., Hobbs, P. V., Kirchstetter, T. W., Magi, B. I., and Sadilek, M.: Water-soluble organic components in aerosols associated with savanna fires in southern Africa: Identification, evolution, and distribution, J. Geophys. Res., 108(D13), 8491, doi:10.1029/2002JD002324, 2003.

Garstang, M., Tyson, P. D., Swap, R., Edwards, M., Kallberg, P., and Lindesay, J. A.: Horizontal and vertical transport of air over southern Africa, J. Geophys. Res., 101(D19), 23721-23736, 1996.

Giglio, L., Descloitres, J., Justice, C. O., and Kaufman, Y. J.: An enhanced contextual fire detection algorithm for MODIS, Remote Sens. Environ., 87(2-3), 273-282, 2003.

Giglio, L., G. R. van der Werf, J. T. Randerson, G. J. Collatz, and P. Kasibhatla, Global estimation of burned area using MODIS active fire observations, Atmos. Chem. Phys., 6, 957-974, 2006, http://www.atmos-chem-phys.net/6/957/2006/.

Ginoux, P., Horowitz, L. W., Ramaswamy, V., Geogdzhayev, I. V., Holben, B. N., Stenchikov, G., and Tie, X.: Evaluation of aerosol distribution and optical depth in the Geophysical Fluid Dynamics Laboratory coupled model CM2.1 for present climate, J. Geophys. Res., 111, D22210, doi:10.1029/2005JD006707, 2006.

Hegg, D. A., Larson, T., and Yuen, P. F.: A theoretical study of the effect of relative humidity on light scattering by tropospheric aerosols, J. Geophys. Res., 98, 18435-18439, 1993.

Hobbs, P. V., Sinha, P., Yokelson, R. J., Bertschi, I. T., Blake, D. R., Gao, S., Kirchstetter, T. W., Novakov, T., and Pilewskie, P.: Evolution of gases and particles from a savanna fire in South Africa, J. Geophys. Res., 108(D13), 8485, doi:10.1029/2002JD002352, 2003.

Kanakidou, M., Seinfeld, J. H., Pandis, S. N., Barnes, I., Dentener, F. J., Facchini, M. C., Van Dingenen, R., Ervens, B., Nenes, A., Nielsen, C. J., Swietlicki, E., Putaud, J. P., Balkanski, Y., Fuzzi, S., Horth, J., Moortgat, G. K., Winterhalter, R., Myhre, C. E. L., Tsigaridis, K., Vignati, E., Stephanou, E. G., and Wilson, J.: Organic aerosol and global climate modelling: a review, Atmos. Chem. Phys., 5, 1053-1123, 2005,

http://www.atmos-chem-phys.net/5/1053/2005/.

Kinne, S., Schulz, M., Textor, C., Guibert, S., Balkanski, Y., Bauer, S. E., Berntsen, T., Berglen, T. F., Boucher, O., Chin, M., Collins, W., Dentener, F., Diehl, T., Easter, R., Feichter, J., Fillmore, D., Ghan, S., Ginoux, P., Gong, S., Grini, A., Hendricks, J., Herzog, M., Horowitz, L., Isaksen, I., Iversen, T., Kirkevåg, A., Kloster, S., Koch, D., Kristjansson, J. E., Krol, M., Lauer, A., Lamarque, J. F., Lesins, G., Liu, X., Lohmann, U., Montanaro, V., Myhre, 
G., Penner, J., Pitari, G., Reddy, S., Seland, O., Stier, P., Takemura, T., and Tie, X.: An AeroCom initial assessment optical properties in aerosol component modules of global models, Atmos. Chem. Phys., 6, 1815-1834, 2006,

http://www.atmos-chem-phys.net/6/1815/2006/.

Kirchstetter, T. W., Novakov, T., Hobbs, P. V., and Magi, B.: Airborne measurements of carbonaceous aerosols in southern Africa during the dry, biomass burning season, J. Geophys. Res., 108(D13), 8476, doi:10.1029/2002JD002171, 2003.

Kirchstetter, T. W., Novakov, T., and Hobbs, P. V.: Evidence that the spectral dependence of light absorption by aerosols is affected by organic carbon, J. Geophys. Res., 109(D21), D21208, 8476, doi:10.1029/2004JD004999, 2004.

Li, J., Posfai, M., Hobbs, P. V., and Buseck, P. R.: Individual aerosol particles from biomass burning in southern Africa: 2. Compositions and aging of inorganic particles, J. Geophys. Res., 108(D13), 8484, doi:10.1029/2002JD002310, 2003.

Liousse, C., Penner, J. E., Chuang, C., Walton, J. J., Eddleman, H., and Cachier, H.: A global three-dimensional model study of carbonaceous aerosols, J. Geophys. Res., 101, 19411-19432, 1996.

Liu, L., Lacis, A. A., Carlson, B. E., Mishchenko, M. I., and Cairns, B.: Assessing Goddard Institute for Space Studies ModelE aerosol climatology using satellite and ground-based measurements: A comparison study, J. Geophys. Res., 111, D20212, doi:10.1029/2006JD007334, 2006.

Maenhaut, W., Salma, I., Cafmeyer, J., Annegarn, H. J., and Andreae, M. O.: Regional atmospheric aerosol composition and sources in the eastern Transvaal, South Africa, and impact of biomass burning, J. Geophys. Res., 101(D19), 23631-23650, 1996.

Magi, B. I. and Hobbs, P. V.: Effects of humidity on aerosols in southern Africa during the biomass burning season, J. Geophys. Res., 108(D13), 8495, doi:10.1029/2002JD002144, 2003.

Magi, B. I., Hobbs, P. V., Schmid, B., and Redemann, J.: Vertical profiles of light scattering, light absorption and single-scattering albedo during the dry, biomass burning season in southern Africa and comparisons of in-situ and remote sensing measurements of aerosol optical depth, J. Geophys. Res., 108(D13), 8504, doi:10.1029/2002JD002361, 2003.

Magi, B. I.: Optical Properties and Radiative Forcing of Southern African Biomass Burning Aerosol, Ph.D. thesis, Univ. of Washington, Seattle, 180 pp., 2006.

Magi, B. I., Fu, Q., Redemann, J., and Schmid, B.: Using aircraft measurements to estimate the magnitude and uncertainty of the shortwave direct radiative forcing of southern African biomass burning aerosol, J. Geophys. Res., 113, D05213, doi:10.1029/2007JD009258, 2008.

Magi, B. I., Ginoux, P. A., Ming, Y., and Ramaswamy, V.: Evaluation of tropical and extratropical Southern Hemisphere African aerosol properties simulated by a climate model, J. Geophys. Res., 114, D14204, doi:10.1029/2008JD011128, 2009.

Matichuk, R. I., Colarco, P. R., Smith, J. A., and Toon, O. B.: Modeling the transport and optical properties of smoke aerosols from African savanna fires during the Southern African Regional Science Initiative campaign (SAFARI 2000), J. Geophys. Res., 112, D08203, doi:10.1029/2006JD007528, 2007.

Mätzler, C., MATLAB Functions for Mie Scattering and Absorption, Institut für Angewandte Physik, Research Report No. 2002-
08, Bern, Switzerland, 2002.

Meehl, G. A., Stocker, T. F., Collins, W. D., Friedlingstein, P., Gaye, A. T., Gregory, J. M., Kitoh, A., Knutti, R., Murphy, J. M., Noda, A., Raper, S. C. B., Watterson, I. G., Weaver, A. J., and Zhao, Z.-C.: Global Climate Projections, in: Climate Change 2007: The Physical Science Basis. Contribution of Working Group I to the Fourth Assessment Report of the Intergovernmental Panel on Climate Change, edited bY: Solomon, S., Qin, D., Manning, M., Chen, Z., Marquis, M., Averyt, K. B., Tignor, M., and Miller, H. L., Cambridge University Press, Cambridge, United Kingdom and New York, NY, USA, 2007.

Piketh, S. J., Annegarn, H. J., and Tyson, P. D.: Lower tropospheric aerosol loadings over South Africa: The relative contribution of aeolian dust, industrial emissions, and biomass burning, J. Geophys. Res., 104(D1), 1597-1607, 1999.

Posfai, M., Simonics, R., Li, J., Hobbs, P. V., and Buseck, P. R.: Individual aerosol particles from biomass burning in southern Africa: 1. Compositions and size distributions of carbonaceous particles, J. Geophys. Res., 108(D13), 8483, doi:10.1029/2002JD002291, 2003.

Ruellan, S., Cachier, H., Gaudichet, A., Masclet, P., and Lacaux, J.: Airborne aerosols over central Africa during the Experiment for Regional Sources and Sinks of Oxidants (EXPRESSO), J. Geophys. Res., 104(D23), 30673-30690, 1999.

Sinha, P., Hobbs, P. V., Yokelson, R. J., Bertschi, I. T., Blake, D. R., Simpson, I. J., Gao, S., Kirchstetter, T. W., and Novakov, T.: Emissions of trace gases and particles from savanna fires in southern Africa, J. Geophys. Res., 108(D13), 8487, doi:10.1029/2002JD002325, 2003a.

Sinha, P., Hobbs, P. V., Yokelson, R. J., Blake, D. R., Gao, S., and Kirchstetter, T. W.: Distributions of trace gases and aerosols during the dry biomass burning season in southern Africa, J. Geophys. Res., 108(D17), 4536, doi:10.1029/2003JD003691, 2003b.

Stier, P., Feichter, J., Kinne, S., Kloster, S., Vignati, E., Wilson, J., Ganzeveld, L., Tegen, I., Werner, M., Balkanski, Y., Schulz, M., Boucher, O., Minikin, A., and Petzold, A.: The aerosolclimate model ECHAM5-HAM, Atmos. Chem. Phys., 5, 11251156, 2005, http://www.atmos-chem-phys.net/5/1125/2005/.

Sun, H., Biedermann, L., and Bond, T. C.: Color of brown carbon: A model for ultraviolet and visible light absorption by organic carbon aerosol, Geophys. Res. Lett., 34, L17813, doi:10.1029/2007GL029797, 2007.

Swap, R. J., Annegarn, H. J., Suttles, J. T., King, M. D., Platnick, S., Privette, J. L., and Scholes, R. J.: Africa burning: A thematic analysis of the Southern African Regional Science Initiative (SAFARI 2000), J. Geophys. Res., 108(D13), 8465, doi:10.1029/2003JD003747, 2003.

Tang, I. N. and Munkelwitz, H. R.: Water activities, densities, and refractive indices of aqueous sulfates and sodium nitrate droplets of atmospheric importance, J. Geophys. Res., 99(D9), 1880118808, 1994.

Tripathi, B. D., Chaturvedi, S. S., and Tripathi, R. D.: Seasonal Variation in Ambient Air Concentration of Nitrate and Sulfate Aerosols in a Tropical City, Varanasi, Atmos. Environ., 30(15), 2773-2778, 1996.

Turpin, B. J. and Lim, H. J.: Species contributions to PM2.5 mass concentrations: Revisiting common assumptions for estimating organic mass, Aerosol Sci. and Tech., 35, 602-610, 2001. 
White, W. H.: The chemical composition of fine particles, Visibility: Existing and Historical Conditions - Causes and Effects, edited by: Trijonis, J. C., US Nat. Acid Precipitation Assess. Prog., Washington DC, 90-94, 1990.
Wild, M.: Short-wave and long-wave surface radiation budgets in GCMs: a review based on the IPCC-AR4/CMIP3 models, Tellus, 60A, 932-945, 2008. 